\title{
Human papillomavirus DNA in surgical smoke during cervical loop electrosurgical excision procedures and its impact on the surgeon
}

This article was published in the following Dove Press journal: Cancer Management and Research

\author{
Qingfeng Zhou',* \\ Xiaoli $\mathrm{Hu}^{\mathrm{l}, *}$ \\ Junhan Zhou' \\ Menghuang Zhao' \\ Xuejie Zhu ${ }^{2}$ \\ Xueqiong Zhu' \\ 'Department of Obstetrics and \\ Gynecology, the Second Affiliated \\ Hospital of Wenzhou Medical University, \\ Wenzhou 325027, People's Republic of \\ China; ${ }^{2}$ Department of Obstetrics and \\ Gynecology, the First Affiliated Hospital \\ of Wenzhou Medical University, \\ Wenzhou 325027, People's Republic of \\ China
}

*These authors contributed equally to this work
Correspondence: Xueqiong Zhu

Department of Obstetrics and Gynecology, the Second Affiliated Hospital of Wenzhou Medical University, No. 109 Xueyuan Xi Road, Wenzhou,

Zhejiang 325027, People's Republic of China

Tel +8657788002796

Fax +8657788832693

Email zjwzzxq@163.com
Objective: The purpose of this study was to explore whether human papillomavirus (HPV) DNA is present in surgical smoke generated by loop electrosurgical excision procedures (LEEPs). Furthermore, we investigated the impact of this HPV DNA on surgeons.

Methods: A total of 134 outpatients with persistent HPV infections treated with LEEP for cervical intraepithelial neoplasia between 2015 and 2016, along with the corresponding LEEP operators, were included. The flow fluorescence in situ hybridization technique was used to detect HPV DNA in exfoliated cervical cells from the patients, in surgical smoke and in nasal epithelial cells from the surgeons before and after LEEP.

Results: The positive rates of HPV DNA in the three types of samples mentioned above were $94.8 \%, 29.9 \%$ and $1.5 \%$, respectively. The distribution of HPV subtypes in surgical smoke was identical to that in the cervical specimens. The positive rate of HPV DNA in surgical smoke was significantly increased for greater distances of the suction device from the surgical site. The nasal epithelial cells of two surgeons were positive for HPV DNA, and the genotypes were consistent with those in the corresponding surgical smoke. After a 3-6-month follow-up, the nasal swabs from these two doctors tested negative for HPV DNA. Conclusions: This study demonstrated the presence of HPV DNA in surgical smoke produced by LEEP and the risk of airborne transmission of HPV DNA during the operation. Fortunately, the HPV DNA in the nasopharynx of the operators was not persistent.

Keywords: HPV, loop electrosurgical excision procedure, surgical smoke, nasal swab

\section{Introduction}

Cervical cancer is the third most common gynecological malignancy worldwide and one of the leading causes of cancer-related death among women in developing countries. ${ }^{1}$ Cervical intraepithelial neoplasia (CIN) is a precancerous cervical lesion that can be confirmed histologically from a biopsy sample. A variety of studies have demonstrated that progression to invasive cancer appears in almost $10-31.3 \%$ of CIN II-III cases within 10-30 years. ${ }^{2,3}$ It has been generally suggested that persistent high-risk human papillomavirus (HPV) infection, especially with HPV 16 and HPV 18, which are the two most carcinogenic HPV genotypes, is the direct cause of cervical carcinogenesis. ${ }^{4}$ Additionally, high-risk HPVs (HR-HPVs) include HPV $16,18,31,33,35,39,45,51,52,56,58,59,66,68$, and 82, and low-risk HPVs (LR-HPVs) include HPV 6, 11, 40, 42, 43, 44, 55, 61, 81, and 83.

In clinical practice, loop electrosurgical excision procedure (LEEP) is generally accepted as an effective and common approach for the diagnosis and treatment of 
high-grade CIN. ${ }^{5}$ Electrosurgery, including LEEP, is a technique to cut tissue and coagulate small vessels by means of a high-frequency electrical current. Surgical smoke is the gaseous byproduct generated by surgical procedures and tools, including electrocautery devices, laser ablation, and ultrasonic scalpels, as a result of the thermal decomposition of tissues. There is substantial evidence indicating the presence of numerous chemicals, blood and tissue particles, viruses, bacteria, and even tumor cells in surgical smoke. ${ }^{6-8}$ Studies have shown that the smoke plume is potentially harmful to surgeons, operating room (OR) personnel, and patients. ${ }^{9}$

In 1990, Abramson et al did not detect HPV DNA in the surgical plume from the vaporization of laryngeal papilloma. ${ }^{10}$ However, subsequent studies have proven the presence of HPV DNA in surgical smoke. ${ }^{11-13}$ Garden et al demonstrated that HPV DNA could be isolated from the smoke plume of papillomavirusinfected warts treated with carbon dioxide lasers. ${ }^{11}$ In addition, a study has suggested that HPV DNA could be detected in LEEP plume, which was collected through a filter placed in the suction tubing, and the prevalence of HPV DNA was high (37\% of the filters). ${ }^{12}$

Several lines of evidence support the hypothesis that HPV DNA may be transmitted through long-term occupational exposure to smoke plume and may subsequently lead to HPV infection and carcinomas. In 1990, a 44year-old laser surgeon developed laryngeal papillomatosis after administering laser therapy to patients with anogenital condylomas due to HPV infection. In situ DNA hybridization of the doctor's laryngeal papilloma tissues revealed HPV types 6 and 11, similar to those found in the patients. ${ }^{13}$ Rioux et al. reported that a 53-year-old male gynecologist who had performed LEEP for over 20 years on more than 3,000 cases of cervical and vulvar dysplasia developed HPV 16-positive tonsillar squamous cell carcinoma. $^{14}$ This doctor had no other risk factors for tonsillar cancer or HPV infection. In addition, the researchers reported that a 62-year-old male gynecologist consequently developed HPV 16-positive tongue carcinoma after administering laser ablation and LEEP for 30 years.

However, almost all related studies on whether HPV DNA in surgical smoke generated by LEEP persists are case reports lacking large-sample studies. Therefore, the purpose of this study was to investigate the prevalence of human papillomavirus DNA in LEEP plume, to confirm whether HPV DNA in surgical smoke leads to HPV infection in surgeons' nasal cells and to demonstrate whether HPV DNA persists in the nasopharynx of these doctors.

\section{Materials and methods}

\section{Patient population}

Our patient population consisted of 134 women operated on between January 2015 and January 2016. These women, aged 24-70 years old (mean, 43.3), underwent LEEP at the Second Affiliated Hospital of Wenzhou Medical University, the First Affiliated Hospital of Wenzhou Medical University, or Wenzhou People's Hospital. The inclusion criteria were as follows: patients with high-grade CIN II-III lesions with high-risk HPV infection, or patients with persistent CIN I lesions with high-risk HPV infection or chronic cervicitis with persistent high-risk HPV infection and continuous postcoital bleeding. In addition, LEEP should have been performed within 2 months preceding HPV detection.

\section{Surgeon population}

A total of 31 gynecologists who performed LEEP for the above outpatients included in our study. The average number of LEEPs included in our study that each operator performed was approximately 4.3. In addition, the doctors' preoperative nasopharyngeal swab specimens were negative for HPV DNA. A total of 268 nasal swab samples were obtained before and after LEEP. The average age of the doctors was 43 years (ranged from 36 to 54 years).

\section{LEEP}

The indications for LEEP in our study included CIN II-III lesions, persistent CIN I lesions or chronic cervicitis with persistent high risk (HR) HPV infections and continuous postcoital bleeding. ${ }^{15}$ LEEP was performed as an outpatient procedure under local anesthesia and colposcopic guidance in the outpatient service system, and a local exhaust suction device was used. An insulated vaginal speculum was used to expose the cervix, followed by application of $5 \%$ acetic acid and Lugol's iodine solutions to assess the lesion. Then, 3-5 mL of $2 \%$ lidocaine plus epinephrine was injected at the $3,6,9$, and 12 o'clock positions on the cervix. The electrosurgical procedure was performed with a high-frequency electrical generator and wire loop electrodes. The loop was selected on the basis of the size of the area to be excised. The appropriate loop electrode was applied to excise the transformation zone under 
colposcopic guidance. The 12 o'clock position in the excised specimen was marked by cutting. The specimen was sent for pathological examination. The operation time of the electroexcision and electrocoagulation procedure ranged from $2 \mathrm{~min}$ to $15 \mathrm{~min}$ (a median of $6 \mathrm{~min}$ ).

Of the surgeons, 93 wore a simple surgical face mask, typically containing three layers, and 41 wore a N95 surgical mask. Additionally, the local smoke evacuation system was always used during the operation. In fact, operators in different hospitals always used suction devices at different distances from the surgical site; some suction tubes were fixed on the metal vaginal speculum near the surgical sites, while others were handheld by the doctors during LEEP. Generally, the distance of the top of the exhaust suction tube from the surgical site was approximately $2-10 \mathrm{~cm}$.

This study was conducted in accordance with the Declaration of Helsinki and was approved by the Ethical Committee of the Second Affiliated Hospital of Wenzhou Medical University. All participants gave their written informed consent.

\section{Sample collection}

Physicians collected exfoliated cervical cells by a CytoBrush, which was placed into $2.5 \mathrm{~mL}$ of a standard transport medium (Tellgen, Shanghai, China), for HPV DNA testing. During LEEP, the smoke plume generated by LEEP was obtained via an aseptic swab $2 \mathrm{~cm}$ away from the surgical site, and the swab was immersed in $1.0 \mathrm{~mL}$ of phosphate-buffered saline (PBS). A new aseptic swab was used for each examination. In addition, preoperative and postoperative nasal swab specimens were collected from the surgeons for the detection of HPV DNA. The nasal swab specimens were obtained from both nostrils at a depth of $2-3 \mathrm{~cm}$ by using a sterile cotton swab, which was then placed into an Eppendorf tube containing 1.0 mL PBS. All specimens were stored at $-20{ }^{\circ} \mathrm{C}$.

\section{Follow-up studies}

The surgeons whose nasopharyngeal wash specimens harbored detectable HPV DNA underwent a nasal swab examination after an additional 3, 6, 12, 18 and 24 months. In addition, in operators testing positive for HPV16 or 58 in the nasopharynx, the presence or absence of HPVrelated diseases such as verruca acuminate was confirmed every 3 months until December 2018 (a follow-up time of 35-43 months).

\section{DNA extraction}

DNA extraction from cervical exfoliated cells was performed according to the manufacturer's instructions (Tellgen, Shanghai, China). Firstly, the cervical specimen was mixed thoroughly in cell storage solution, and cervical cells in a $200 \mu \mathrm{L}$ volume were transferred to a $1.5 \mathrm{~mL}$ Eppendorf tube and centrifuged at $13,000 \mathrm{rpm}$ for $10 \mathrm{~min}$. Then, the supernatant was removed. The cell pellet was resuspended in $200 \mu \mathrm{L}$ of denaturing reagent (Tellgen, Shanghai, China) for DNA extraction. The mixture was shaken thoroughly and incubated at $100{ }^{\circ} \mathrm{C}$ for $10 \mathrm{~min}$. The solution was centrifuged at $13,000 \mathrm{rpm}$ for $10 \mathrm{~min}$, and $100 \mu \mathrm{L}$ of the supernatant was transferred to another $1.5 \mathrm{~mL}$ Eppendorf tube for HPV genotype analysis. The extracted DNA was analyzed immediately or stored at $-20{ }^{\circ} \mathrm{C}$ until use.

Additionally, a high-purity viral nucleic acid kit (Roche, Mannheim, Germany) was used to extract DNA from surgical smoke and nasal epithelial cells according to the manufacturer's protocol. Then, $50 \mu \mathrm{L}$ of proteinase $\mathrm{K}$ solution and $200 \mu \mathrm{L}$ of carrier RNA working solution were added into the sample solution $(200 \mu \mathrm{L})$ in a $1.5 \mathrm{~mL}$ Eppendorf tube, followed by incubation of the tightly closed tube at $72{ }^{\circ} \mathrm{C}$ for $10 \mathrm{~min}$. After incubation, $100 \mu \mathrm{L}$ of binding buffer was added and mixed immediately. Then, the whole solution was transferred to a highpurity filter tube and centrifuged at 8,000 rpm for $1 \mathrm{~min}$. After centrifugation, $500 \mu \mathrm{L}$ of Inhibitor Removal Buffer was added to the supernatant from the filter tube. The buffer was centrifuged at $8,000 \mathrm{rpm}$ for $1 \mathrm{~min}$, and $450 \mu \mathrm{L}$ of Wash Buffer was added to the upper reservoir of the filter tube and centrifuged at 8,000 rpm for $1 \mathrm{~min}$. After these purification steps were repeated twice, the residual Wash Buffer was centrifuged at 13,000 rpm for $10 \mathrm{~s}$. Then, the filter tube was inserted into a nuclease-free, sterile $1.5 \mathrm{~mL}$ microcentrifuge tube, and the purified DNA was eluted in $50 \mu \mathrm{L}$ of Elution Buffer. Then, the highly purified DNA sample was collected by centrifugation at $8,000 \mathrm{rpm}$ for $1 \mathrm{~min}$ and stored at $-20{ }^{\circ} \mathrm{C}$. ${ }^{16}$

\section{DNA sample quality assessment}

The optical density (OD) of the extracted DNA samples was calculated from the absorbance ratio at $260 \mathrm{~nm} /$ $280 \mathrm{~nm}$ measured in a Protein Nucleic Acid Analyzer. The OD 260/280 value of the DNA samples ranged from 1.6-2.0. In addition, the human $\beta$-globin gene was detectable in the collected DNA samples, indicating the adequacy of the specimen for DNA amplification. 


\section{HPV genotyping by hybridization}

HPV genotyping by hybridization was performed using a Tellgenplex ${ }^{\mathrm{TM}}$ HPV DNA Test (Tellgen, Shanghai, China) according to the manufacturer's instructions. This assay can detect $27 \mathrm{HPV}$ types, including 17 high-risk HPV types (HPV16, 18, 26, 31, 33, 35, 39, 45, 51, 52, 53, 56, 58, 59, 66, 68 and 82) and 10 low-risk HPV types (HPV6, 11, 40, 42, 43, 44, 55, 61, 81 and 83) by the flowthrough hybridization technique using HPV DNA amplified by polymerase chain reaction (PCR). A positive control and a negative control were included in each PCR analysis process. PCR was carried out in a $20 \mu \mathrm{L}$ volume per person. In addition, the PCR master mix was prepared by mixing $5 \mu \mathrm{L}$ of primer mixture, $10 \mu \mathrm{L}$ of PCR premix solution, $0.8 \mu \mathrm{L}$ of Taq DNA polymerase and $5 \mu \mathrm{L}$ of extracted DNA. PCR was initiated with a $5 \mathrm{~min}$ step at $95{ }^{\circ} \mathrm{C}$ followed by 5 cycles of denaturation at $95^{\circ} \mathrm{C}$ for $30 \mathrm{~s}$, annealing at $58^{\circ} \mathrm{C}$ for $30 \mathrm{~s}$ and elongation at $72{ }^{\circ} \mathrm{C}$ for $30 \mathrm{~s}$. Thereafter, 35 cycles at $95{ }^{\circ} \mathrm{C}$ for $30 \mathrm{~s}, 55^{\circ} \mathrm{C}$ for $30 \mathrm{~s}$ and $72{ }^{\circ} \mathrm{C}$ for $30 \mathrm{~s}$ were performed, with a final extension step at $72{ }^{\circ} \mathrm{C}$ for $3 \mathrm{~min}$. In total, 40 cycles were performed.

Fluorescence in situ hybridization was performed in a preheated instrument at $45{ }^{\circ} \mathrm{C} ; 22 \mu \mathrm{L}$ of hybridization solution and $3 \mu \mathrm{L}$ of PCR product per well were added to 96-well microtiter plates (Tellgen, Shanghai, China). The negative control was analyzed simultaneously. The conditions used for hybridization were $95^{\circ} \mathrm{C}$ for $5 \mathrm{~min}$ and $48^{\circ} \mathrm{C}$ for $30 \mathrm{~min}$. After hybridization, $75 \mu \mathrm{L}$ of streptavidinR-phycoerythrin was added to each well of the 96-well microtiter plate, and the reactions were carried out by incubation at $48{ }^{\circ} \mathrm{C}$ for $15 \mathrm{~min}$. Finally, the product was detected by a Luminex 200 analyzer (Luminex Corporation, Austin, TX). The HPV genotype result was determined according to the positions of the HPV genotype probes on the microarray chip. Multiple dots indicated multiple infections.

\section{HPV genotyping by PCR}

The type-specific E6 primers shown in Table 1 were designed to detect the six most common types of highrisk HPV in exfoliated cervical cells, including HPV16, 18, 31, 33, 52, and 58, by PCR. ${ }^{17-19}$ All oligonucleotide primers were obtained from Sangon Biotech (Shanghai) Co., Ltd. and Yingjun (Shanghai) Co., Ltd. As the control for DNA extraction, the $\beta$-globin primer pair $\mathrm{PC} 04 / \mathrm{GH} 20$ was used. The $20 \mu \mathrm{L}$ volume of the PCR mixture contained $0.4 \mu \mathrm{L}$ of the forward primer, $0.4 \mu \mathrm{L}$ of the reverse primer, $10 \mu \mathrm{L}$ of PCR master mix, $2 \mu \mathrm{L}$ of extracted DNA, and $7.2 \mu \mathrm{L}$ of sterile ultrapure water. HPV detection was attempted using three different PCR conditions. The standard PCR conditions for amplifying the HPV $\beta$-globin gene were a denaturing step at $95{ }^{\circ} \mathrm{C}$ for $5 \mathrm{~min}$; followed by 40 cycles of $1 \mathrm{~min}$ at $95{ }^{\circ} \mathrm{C}, 1 \mathrm{~min}$ at the appropriate annealing temperature, and $2 \mathrm{~min}$ at $72{ }^{\circ} \mathrm{C}$; and a final extension step at $72{ }^{\circ} \mathrm{C}$ for $5 \mathrm{~min}$. The second PCR protocol was attempted for the detection of HPV 16 and 18 : a denaturing step at $95^{\circ} \mathrm{C}$ for $5 \mathrm{~min}$; followed by 40 cycles of $1 \mathrm{~min}$ at $94{ }^{\circ} \mathrm{C}, 1 \mathrm{~min}$ at $55^{\circ} \mathrm{C}$, and $1 \mathrm{~min}$ at $72{ }^{\circ} \mathrm{C}$; and an extension step at $72{ }^{\circ} \mathrm{C}$ for $7 \mathrm{~min}$. In addition, the third set of PCR conditions for amplifying DNA from HPV31, 33,52 , and 58 were as follows: a denaturing step at $95{ }^{\circ} \mathrm{C}$ for $5 \mathrm{~min}$; followed by 40 cycles of 30 seconds at $94{ }^{\circ} \mathrm{C}$, 30 seconds at $60{ }^{\circ} \mathrm{C}$, and $1 \mathrm{~min}$ at $72{ }^{\circ} \mathrm{C}$; and a final

Table I Specifications of oligonucleotides used as primers and probes for HPV detection by PCR

\begin{tabular}{|c|c|c|c|c|}
\hline Primer & & Sequence & Amplicon & Reference \\
\hline HPVI6 E6 & $\begin{array}{l}\text { Forward primer } \\
\text { Reverse primer }\end{array}$ & $\begin{array}{l}\text { 5'CACAGTTATGCACAGAGCTGC 3' } \\
\text { 5'CATATATTCATGCAATGTAGGTGTA 3, }\end{array}$ & 457 bp & 17 \\
\hline HPVI8 E6 & $\begin{array}{l}\text { Forward primer } \\
\text { Reverse primer }\end{array}$ & $\begin{array}{l}\text { 5'CACTTCACTGCAAGACATAGA 3' } \\
\text { 5'GTTGTGAAATCGTCGTTTTTCA 3' }\end{array}$ & 322 bp & 17 \\
\hline HPV3I E6 & $\begin{array}{l}\text { Forward primer } \\
\text { Reverse primer }\end{array}$ & $\begin{array}{l}\text { 5'AAAAGTAGGGAGTGACCGAAAGTGG 3' } \\
\text { 5'TCGGGTAATTGCTCATAACAGTGGA 3' }\end{array}$ & $625 \mathrm{bp}$ & 18 \\
\hline HPV33 E6 & $\begin{array}{l}\text { Forward primer } \\
\text { Reverse primer }\end{array}$ & $\begin{array}{l}\text { 5'ATGATAGATGATGTAACGCC 3' } \\
\text { 5'GCACACTCCATGCGTATCAG 3' }\end{array}$ & $470 \mathrm{bp}$ & 19 \\
\hline HPV52 E6 & $\begin{array}{l}\text { Forward primer } \\
\text { Reverse primer }\end{array}$ & $\begin{array}{l}\text { 5'ACGCACGGCCATGTTTGAGGAT 3' } \\
\text { 5'TAATTGCTTGTGGCTTGTTCTGCTTGTC 3' }\end{array}$ & $622 \mathrm{bp}$ & 18 \\
\hline HPV58 E6 & $\begin{array}{l}\text { Forward primer } \\
\text { Reverse primer }\end{array}$ & $\begin{array}{l}\text { 5'AGGCTACTGCAGGACTATGTTC 3' } \\
\text { 5'AGCGTTGGGTTGTTTCCTCTCA 3' }\end{array}$ & $503 \mathrm{bp}$ & 18 \\
\hline$\beta$-globin & $\begin{array}{l}\text { Forward primer } \\
\text { Reverse primer }\end{array}$ & $\begin{array}{l}\text { 5'GAAGAGCCAAGGACAGGTAC 3' } \\
\text { 5'CAACTTCATCCACGTTCACC 3' }\end{array}$ & $260 \mathrm{bp}$ & \\
\hline
\end{tabular}


extension step at $72{ }^{\circ} \mathrm{C}$ for $7 \mathrm{~min}$. After PCR, $8 \mu \mathrm{L}$ of all samples was run on a $2 \%$ agarose gel including GoldView I nucleic acid and visualized under ultraviolet light. A digital image of the gel was acquired in a gel documentation system (Bio-Rad, USA), and the specific HPV type was determined by matching the restriction fragment patterns of the respective specimens to those of known HPV controls.

\section{Statistical analysis}

To determine the correlation between the flow fluorescence in situ hybridization method and the PCR assay, the Kappa test was applied, and the reference values adopted were assessed according to the evaluation criteria described by Altman. $^{20}$ The HPV genotypes, including HPV16, 18, 31, 33, 52 and 58, which could be detected by both methods were considered in the comparison. A Kappa value of 0 implies no agreement, and a value of 1 indicates perfect agreement. Values from $0.00-0.20$ indicate poor agreement; $0.21-0.40$, fair; $0.41-0.60$, moderate; $0.61-0.80$, good; and $0.81-0.99$, very good. Statistical analysis was performed using SPSS 17.0 statistical software (SPSS, Chicago, IL, USA). The relevant factors were analyzed by the Chisquare test. The independent variables that were significant for HPV infection from surgical smoke were included in the logistic regression analyses. A 2-tailed $P$-value of 0.05 or less was considered statistically significant.

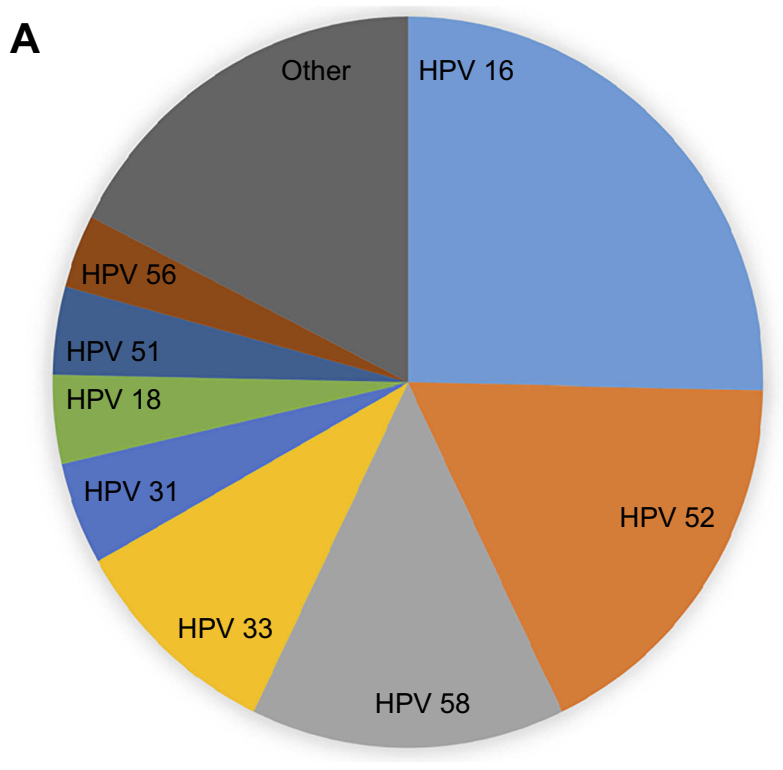

\section{Results \\ HPV DNA in patients' exfoliated cervical cells}

A total of 134 women with persistent high-risk HPV infections and diagnosed with CIN II-III lesions or with persistent CIN I lesions and the corresponding doctors who participated in LEEP were enrolled in this study. Moreover, HPV DNA in cervical cells, surgical smoke and nasal epithelial cells was detected by using two different methods: flow fluorescence in situ hybridization and a traditional PCR assay.

The HPV genotypes identified in cervical cells by the hybridization technique are presented in Figure 1A. This result indicated a total of $154 \mathrm{HPV}$ infections in 134 samples positive for DNA of single or multiple HPV types. Among the samples, HPV 16, which was the most common type, was detected in 29.1\% (39/134), followed by HPV 52 (26/134), 58 (23/134), 33 (14/134), 31 (8/134), 18 (6/134), 51 (6/134), and $56(5 / 134)$. High-risk (HR) types were found in 120/134 $(89.6 \%)$ samples, and low-risk (LR) types were identified in 12/134 (9.0\%) samples. Moreover, one genotype of HPV DNA was detected in $100(74.6 \%)$ of the cervical cell samples, two different genotypes of HPV DNA were detected in 27 (20.1\%), and 7 (5.2\%) specimens had no detectable HPV DNA by flow fluorescence in situ hybridization. The distribution of HPV subtypes in the exfoliated cervical cells was consistent with the HPV genotypes identified in these patients during preoperative examination.

B

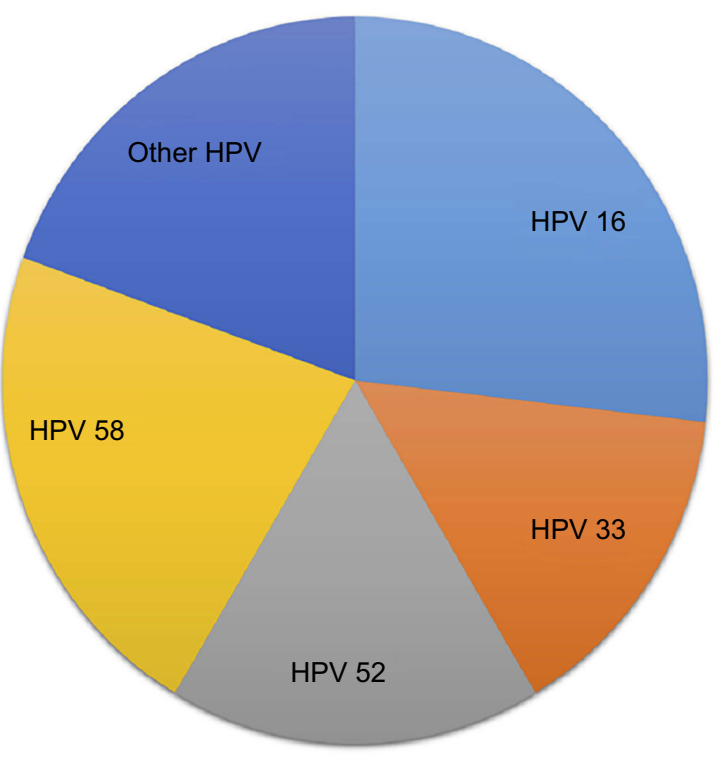

Figure I (A) HPV genotypes identified in exfoliated cervical cells via the flow fluorescence in situ hybridization technique. (B) HPV genotypes identified in surgical smoke via the flow fluorescence in situ hybridization technique. 
Six HPV subtypes-HPV16, 18, 31, 33, 52, and 58were the subtypes most frequently detected by the hybridization technique in our study. Thus, we further evaluated these six HR-HPV DNA genotypes using a PCR assay in exfoliated cervical cell, surgical plume and nasal epithelial cell samples. As shown in Table 2, of the 134 cervical cell samples assayed by PCR, 93 (69.4\%) had detectable HPV DNA, and 41 (30.6\%) had no detectable HPV DNA of any of these six subtypes. In addition, HPV16 was the most common subtype, detected in $23.1 \%$ (31/134) of the samples, followed by HPV58, 52, 33, 31 and 18 . There were 84 (62.7\%) samples in which one genotype of HPV DNA was detected, and 9 (6.7\%) with dual HPV infection. The HPV subtypes in exfoliated cervical cells detected by PCR assay were also detected in the corresponding patients' preoperative examinations. Currently, two major HR-HPV testing methods are used in China: the hybrid capture method and flow fluorescence hybridization, which includes PCR and reverse dot blot hybridization. Flow fluorescence hybridization, which is also called the Tellgenplex HPV DNA test, has a high sensitivity and specificity. However, this test can also produce many false positive results. Thus, PCR, as

Table 2 HPV infections detected by flow fluorescence in situ hybridization and a conventional PCR assay in exfoliated cervical cells and surgical smoke. A PCR assay was used to detect the six most common HPV genotypes in exfoliated cervical cells

\begin{tabular}{|l|l|l|l|}
\hline Method & $\begin{array}{l}\text { HPV } \\
\text { DNA }\end{array}$ & $\begin{array}{l}\text { Exfoliated cer- } \\
\text { vical cells (\%) }\end{array}$ & $\begin{array}{l}\text { Surgical } \\
\text { smoke (\%) }\end{array}$ \\
\hline $\begin{array}{l}\text { Fluorescence } \\
\text { hybridization }\end{array}$ & Positive & $127(94.8 \%)$ & $40(29.9 \%)$ \\
& Negative & $7(5.2 \%)$ & $94(70.1 \%)$ \\
& Total & 134 & 134 \\
PCR assay & Positive & $93(69.4 \%)$ & $30(22.4 \%)$ \\
& Negative & $41(30.6 \%)$ & $99(73.9 \%)$ \\
& Total & 134 & 134 \\
\hline
\end{tabular}

a traditional method for detecting HPV DNA, was used to identify the HPV genotypes in this study. As shown in Table 3, there was good concordance between the hybridization technique and PCR assay for HPV detection (k: 0.7, $P<0.001)$. Additionally, the overall level of agreement was $88.1 \%$. However, the PCR assay failed to detect HPV DNA in 15 cervical cell specimens in which HPV DNA was detected by the flow fluorescence in situ hybridization technique. In addition, HPV DNA was detected by PCR in 2 cervical cell samples in which it could not be detected by flow fluorescence in situ hybridization.

Therefore, we concluded that HPV16, 18, 31, 33, 52 and 58 were the 6 most common HPV types that could infect patients with cervical lesions, and HPV16 was determined to be the most prevalent genotype by two different methods. In addition, good concordance between the hybridization technique and PCR assay in terms of HPV detection was further demonstrated.

\section{HPV DNA in surgical smoke}

A total of 40 of the 134 surgical smoke samples $(29.9 \%)$ were positive for HPV DNA by flow fluorescence in situ hybridization. The specific distribution of the HPV subtypes in cervical cells and LEEP plume is shown in Table 4. HPV16 (11/134, 8.2\%) was the most common type, followed by HPV58 (9/134, 6.7\%), HPV52 (7/134, 5.2\%), HPV33 (6/134, 4.5\%), HPV31 (2/134, 1.5\%) and HPV18 (2/134, 1.5\%). In addition, single HPV infections (39/134, 29.1\%) and dual HPV infections with HPV52 and 58 DNA $(1 / 134,0.7 \%)$ were detected in smoke plume samples. As shown in Figure 1B, HPV 16 was detected in 27.5\% (11/40) of the smoke plume specimens and was the most common subtype found in the HPV DNA-positive LEEP plume specimens, followed by HPV 58 (9/40), 52 (7/40), 33 (6/ 40), 31 (2/40), 18 (2/40), 68 (2/40), 53 (1/40) and $56(1 / 40)$. Additionally, HPV DNA positivity in the exfoliated cervical

Table 3 Concordance and agreement for HPV detection by using flow fluorescence in situ hybridization and a PCR assay in exfoliated cervical cells. A PCR assay was used to detect the six most common HPV genotypes in exfoliated cervical cells

\begin{tabular}{|c|c|c|c|c|c|c|c|}
\hline & \multicolumn{3}{|c|}{ PCR assay } & \multirow[t]{2}{*}{$\mathbf{k}^{\mathbf{b}}$} & \multirow[t]{2}{*}{ Agreement (\%) } & \multirow[t]{2}{*}{$\mathbf{Z}$} & \multirow[t]{2}{*}{$P$-value } \\
\hline & Positive & Negative & Total & & & & \\
\hline \multicolumn{8}{|c|}{ Fluorescence method } \\
\hline Positive & 91 & 15 & 106 & 0.7 & 88.1 & 8.3 & $<0.001$ \\
\hline Negative & 2 & 26 & 28 & & & & \\
\hline Total & 93 & 41 & 134 & & & & \\
\hline
\end{tabular}

Notes: HPV positivity included HPV 16, 18, 31, 33, 52, 58. ' Cohen's Kappa. 
Table 4 Detection of specific HPV genotypes by flow fluorescence in situ hybridization in exfoliated cervical cells, surgical plume and LEEP operators' nasal swab samples

\begin{tabular}{|c|c|c|c|}
\hline $\begin{array}{l}\text { No. of } \\
\text { patients }\end{array}$ & $\begin{array}{l}\text { Cervical } \\
\text { cells }\end{array}$ & $\begin{array}{l}\text { Surgical } \\
\text { plume }\end{array}$ & $\begin{array}{l}\text { Nasal } \\
\text { swab }\end{array}$ \\
\hline Case I & $31 / 58$ & 58 & Negative \\
\hline Case 2 & 16 & 16 & Negative \\
\hline Case 3 & 16 & 16 & 16 \\
\hline Case 4 & 16 & 16 & Negative \\
\hline Case 5 & 68 & 68 & Negative \\
\hline Case 6 & 58 & 58 & Negative \\
\hline Case 7 & 16 & 16 & Negative \\
\hline Case 8 & 16 & 16 & Negative \\
\hline Case 9 & 58 & 58 & Negative \\
\hline Case 10 & 31 & 31 & Negative \\
\hline Case II & 18 & 18 & Negative \\
\hline Case 12 & 33 & 33 & Negative \\
\hline Case 13 & 68 & 68 & Negative \\
\hline Case 14 & 16 & 16 & Negative \\
\hline Case 15 & 58 & 58 & Negative \\
\hline Case 16 & $33 / 53$ & 33 & Negative \\
\hline Case 17 & $33 / 56$ & 33 & Negative \\
\hline Case 18 & 16 & 16 & Negative \\
\hline Case 19 & 52 & 52 & Negative \\
\hline Case 20 & 33 & 33 & Negative \\
\hline Case 21 & 52 & 52 & Negative \\
\hline Case 22 & $16 / 44$ & 16 & Negative \\
\hline Case 23 & $52 / 58$ & 58 & Negative \\
\hline Case 24 & 52 & 52 & Negative \\
\hline Case 25 & $52 / 58$ & $52 / 58$ & Negative \\
\hline Case 26 & $31 / 52$ & 31 & Negative \\
\hline Case 27 & 52 & 52 & Negative \\
\hline Case 28 & 52 & 52 & Negative \\
\hline Case 29 & 52 & 52 & Negative \\
\hline Case 30 & $33 / 53$ & 33 & Negative \\
\hline Case 31 & 56 & 56 & Negative \\
\hline Case 32 & 18 & 18 & Negative \\
\hline Case 33 & 53 & 53 & Negative \\
\hline Case 34 & 16 & 16 & Negative \\
\hline Case 35 & 58 & 58 & Negative \\
\hline Case 36 & 16 & 16 & Negative \\
\hline Case 37 & 58 & 58 & 58 \\
\hline Case 38 & 16 & 16 & Negative \\
\hline Case 39 & 33 & 33 & Negative \\
\hline Case 40 & 58 & 58 & Negative \\
\hline
\end{tabular}

cells was significantly associated with HPV DNA positivity in the surgical plume, as shown in Table S1.

In the PCR assay, 30 (22.4\%) smoke plume specimens were positive for one of the six most common HPV DNA subtypes; two samples (1.5\%) were positive for two subtypes of HPV, including HPV31/58 and HPV52/58, and 28 (20.9\%) were positive for one HPV subtype. Moreover, the
HPV subtypes detected in smoke plume samples by PCR assay were HPV58 (9/134, 6.7\%), HPV16 (7/134, 5.2\%), HPV52 (6/134, 4.5\%), HPV33 (5/134, 3.7\%), HPV31 (3/ 134, 2.2\%) and HPV18 (2/134, 1.5\%), consistent with the HPV subtypes found in these outpatients during the preoperative examination. Additionally, Table 2 shows the distribution of diagnoses with the two different methods of detecting HPV DNA in surgical smoke.

\section{HPV DNA in operators' nasal epithelial cells}

All nasal epithelial cells obtained from the doctors' preoperative nasal swabs were negative for HPV DNA. Among the operators, $70.1 \%(94 / 134)$ wore an ordinary mask, and the others $(29.9 \%, 40 / 134)$ wore a special N95 surgical mask. However, 2 (1.5\%) of the 134 swabs obtained from the nasopharynx postoperatively were positive for HPV: one was positive for HPV 16, and the other was positive for HPV 58. These two HPV subtypes were detected in operators who wore the ordinary face mask when operating LEEP. Moreover, the distribution of HPV subtypes in the operators' nasal swabs was consistent with the genotypes detected in the corresponding cervical cells and surgical smoke samples. The same results were obtained for nasal swabs by flow fluorescence in situ hybridization and PCR assay. In addition, the operators whose nasal swabs were positive for HPV underwent a nasal swab examination after an additional 3, 6, 12, 18 and 24 months; one operator tested negative for HPV16 DNA at the 3-month examination, and the other operator tested negative for HPV58 at 6 months. Additionally, both nasal swabs were negative for HPV DNA at the subsequent examinations at 12 months and 24 months. Furthermore, these doctors with nasal swabs positive for HPV16 or 58 were confirmed to have no HPV-related diseases, such as verruca acuminate, every 3 months during the subsequent 35 and 43 months, respectively.

\section{Risk factors for the presence of HPV DNA in the surgical plume}

The risk factors for the existence of HPV DNA in surgical smoke are presented in Table 5. Among the 134 cervical cell samples that were positive for HPV DNA, the positive rates of HPV DNA in surgical smoke determined by the hybridization technique at different distances from the suction device to the surgical site $(\mathrm{d}<3,3 \leq \mathrm{d} \leq 5,6 \leq \mathrm{d} \leq 7$, and $\mathrm{d}>7 \mathrm{~cm}$ ) were $9.1 \%, 15.3 \%, 45.1 \%$ and $53.9 \%$, 
Table 5 Correlation of HPV DNA in surgical smoke with the distance of the suction device from the surgical site, operation time and pathological grade

\begin{tabular}{|c|c|c|c|c|}
\hline \multirow[t]{2}{*}{ Factor } & \multicolumn{2}{|c|}{$\begin{array}{l}\text { HPV infection in } \\
\text { surgical smoke }\end{array}$} & \multirow[t]{2}{*}{$\begin{array}{l}\chi^{2} \\
\text { value }\end{array}$} & \multirow[t]{2}{*}{$P$-value } \\
\hline & $\begin{array}{l}\text { Positive } \\
\text { (Positive } \\
\text { rate) }\end{array}$ & Negative & & \\
\hline $\begin{array}{l}\text { Distance of the } \\
\text { suction device } \\
\text { from the surgical } \\
\text { site }(\mathrm{cm}) \\
d<3 \\
3 \leq d \leq 5 \\
6 \leq d \leq 7 \\
d>7\end{array}$ & $\begin{array}{l}\text { I (9.1\%) } \\
9(15.3 \%) \\
23(45.1 \%) \\
7(53.9 \%)\end{array}$ & $\begin{array}{l}10 \\
50 \\
28 \\
6\end{array}$ & 17.5 & 0.001 \\
\hline $\begin{array}{l}\text { Surgical time } \\
(\min )\end{array}$ & & & 1.4 & 0.833 \\
\hline $\mathrm{I} \leq \mathrm{t}<2.5$ & $0(0)$ & 4 & & \\
\hline $2.5 \leq t<5$ & 9 (26.5\%) & 25 & & \\
\hline $5 \leq t<7.5$ & 24 (32.9\%) & 49 & & \\
\hline $7.5 \leq t<10$ & $3(30.0 \%)$ & 7 & & \\
\hline $\mathrm{t} \geq 10$ & $4(30.8 \%)$ & 9 & & \\
\hline $\begin{array}{l}\text { Cervical patho- } \\
\text { logical grade }\end{array}$ & & & 2.3 & 0.489 \\
\hline $\begin{array}{l}\text { Chronic } \\
\text { cervicitis }\end{array}$ & $0(0)$ & 4 & & \\
\hline CIN I & 14 (37.8\%) & 23 & & \\
\hline CIN II & $23(28.0 \%)$ & 59 & & \\
\hline CIN III & 3 (27.3\%) & 8 & & \\
\hline
\end{tabular}

Abbreviations: $\mathrm{CIN}$, cervical intraepithelial neoplasia; $d$, distance; $t$, time.

respectively. The Chi-square test revealed that positive rate of HPV DNA in surgical smoke was significantly higher in samples obtained at a greater distance between the suction device and surgical site $(P=0.000)$. Therefore, the distance between the suction device and surgical site was positively associated with the presence of HPV DNA in surgical smoke. However, the operation time and pathological grade were not significantly correlated with the presence of HPV DNA in surgical smoke. As shown in Table S2, logistic regression analysis revealed that the location of the suction device from the surgical site influenced the presence of HPV DNA in surgical smoke (OR $=5.0,95 \%$ $\mathrm{CI}=1.4-17.6$ ).

\section{Discussion}

From this study, it is clear that human papillomavirus DNA is present in smoke plume generated by LEEP and that HPV DNA could be transmitted from patients to operators. Fortunately, HPV DNA positivity was not persistent in the nasopharynx of LEEP operators, and these operators did not exhibit HPV DNA-related disease or cervical cancer in the subsequent 35-43 months.

The increased use of electrocautery and laser treatment in recent years has increased the amount of exposure to surgical smoke. Surgical smoke is called by a variety of names, including plume, smoke plume, diathermy plume, cautery smoke, aerosols, bioaerosols, vapors, and air contaminants. Smoke plumes are created when hightemperature devices such as electrosurgical units and LEEP equipment are used to vaporize, coagulate, or ablate tissue, causing cellular contents to be released into the air. The carcinogenic potential of chemicals in this smoke was already assumed in the $1980 \mathrm{~s}$, and there has been a growing interest in the potential adverse health effects of exposure to particles in surgical smoke. ${ }^{21}$ It has been estimated that $90 \%$ of endoscopic and surgical procedures produce surgical smoke and that 350,000 healthcare workers are exposed to this smoke or smoke plume annually. ${ }^{22}$

Electrosurgery, especially LEEP, uses low-voltage, high-frequency radio waves transmitted through a thin wire loop to accomplish surgical effects. Lateral necrosis or coagulation depends on the current mode, intensity, frequency, impedance, and operating mode. Electrosurgery may cause less tissue destruction than laser surgery but may liberate more intact cells that contain viral DNA, which may be more infectious than other vectors. Sood et al reported that thirty-nine (80\%) cervical tissue samples from CIN patients were positive for HPV as determined by PCR assays incorporating L1 consensus primers. ${ }^{12}$ Furthermore, previous studies demonstrated that HPV DNA can be isolated from $\mathrm{CO}_{2}$ laser smoke generated during the treatment of plantar warts, ${ }^{11,23}$ from the surgical smoke generated by LEEP, ${ }^{12}$ and from laser smoke generated during the treatment of recurrent respiratory papillomatosis. ${ }^{24}$ Weyandt et al recovered HPV DNA from the filters of $\mathrm{CO}_{2}$ lasers during the treatment of genital warts. ${ }^{25}$ Sood et al reported that HPV DNA was detected in 18 (37\%) filters used in LEEP and that the DNA sequencing results indicated identical HPV subtypes in the corresponding tissues and filters. ${ }^{12}$ Additionally, Ferenczy et al proved the presence of HPV DNA in laser vapor generated during the treatment of anogenital condyloma. ${ }^{23}$ These results further revealed the negative effect of infectious HPV particles on healthcare professionals in recent decades, such as the airborne transmission of HPV DNA and the development of nasopharyngeal 
cancer. ${ }^{14}$ However, the infectivity of HPV DNA from HPV DNA-related operations remains unclear.

HPV infection is believed to be the main cause of cervical cancer, and it is estimated that HPV DNA is present in over $99 \%$ of these cancers. ${ }^{21}$ Thus, HPV detection and typing methods are very important for discovering early HPV infection. In recent years, the flow cytometry fluorescence in situ hybridization method has emerged as a highly sensitive method widely used in the detection of HPV DNA. PCR assays are the most commonly used method and are currently validated for HPV DNA detection. In this study, the fluorescence technique was used for the detection of HPV in cervical cells, smoke plume generated by LEEP and nasal swabs from the operators. Furthermore, a PCR assay was performed to evaluate the presence of the six most common HPV DNA types (HPV16, 18, 31, 33, 52 and 58) detected by the fluorescence hybridization method. Our study demonstrates good concordance between the fluorescence hybridization method and PCR assays for detecting HPV DNA in cervical tissue. Moreover, the positive detection rates of the predominant subtypes were verified by the above two methods.

In addition, as determined by the flow fluorescence in situ hybridization technique, the prevalence rates of HPV in this study were $94.8 \%$ (127/134) in cervical cells, 69.4\% (40/ $134)$ in surgical smoke and $1.5 \%(2 / 134)$ in postoperatively collected nasal epithelial cells. Although no HPV DNA was detected in these 7 patients' exfoliated cervical cell samples, individuals positive for HPV DNA in the preoperative examination were included in our study. The reasons that HPV DNA could not be detected in the above 7 included patients' cervical tissues by fluorescence hybridization or PCR were as follows: 1. The copy numbers of HPV DNA were near the detection threshold, which could result in positive detection before the LEEP operation but negative results during surgery. 2. The patients tested positive for HPV DNA preoperatively. However, HPV infection was not persistent, which may produce negative results during LEEP 1-2 months after the preoperative measurement. 3. HPV-positive detection may have been performed in other hospitals, in which the detection threshold for HPV was slightly lower than the positive value measured in our hospital. Among the HPVpositive cervical cell samples, the prevalence of the HPV16 genotype was $29.1 \%(39 / 134)$; the prevalence decreased in the order of HPV52, 58, 33, 31 and 18. In addition, multiple subtypes were present in 27 samples. HPV16 was also the most prevalent genotype in surgical smoke samples. Wang et al showed that the most prevalent HPV genotypes in 37 Chinese cities were HPV16 (4.8\%) and HPV52 (4.5\%), followed by HPV58 (2.7\%). These results were identical to our findings. 22

The subsequent data show that 40 samples of surgical smoke were positive for HPV DNA and that the genotypes matched those previously detected in cervical cell samples by the flow fluorescence in situ hybridization technique. In addition, the results of the PCR assay in surgical smoke samples were consistent with the HPV DNA subtypes detected in cervical tissue samples. Thus, the infective capability of the HPV particles released during LEEP was confirmed by our findings.

In addition, HPV DNA was detected in two operators' nasal swab specimens; one was positive for HPV 16, and the other was positive for HPV 58. The HPV subtypes were consistent with the genotypes detected in the smoke plume generated by LEEP. These results revealed that HPV DNA could be transmitted from patients to doctors through surgical smoke. Thus, surgical smoke produced by LEEP could lead to HPV infection in surgeons.

In our study, it was shown that the presence of HPV in surgical smoke was associated with the distance from the suction device to the surgical site. Our findings revealed a significantly increased incidence of HPV infection when the suction tube was placed at a greater distance from the surgical site. Logistic regression analysis showed that locating the suction device at a greater distance from the surgical site conferred a greater risk of HPV infection from surgical smoke released during LEEP (OR $=4.973$, 95\% CI: 1.404-17.618). This result demonstrated that decreasing the distance from the suction device to the surgical site could effectively decrease the risk of HPV infection from surgical smoke. Using smoke evacuators, such as exhaust suction devices alone, may not be sufficient to completly remove surgical smoke generated by LEEP. In addition, LEEP was performed on all included patients by using a local suction device in the outpatient clinic. It is possible that the positive rate of HPV DNA in surgical smoke from LEEP was lower in the inpatient department, in which a central suction device was usually used, than in the outpatient clinic. Further research is needed to clarify the impact of different suction devices on the presence of HPV DNA in surgical smoke. It is obvious that respiratory masks play a vital role in efficient protection from HPV infection. Surgical masks are the most frequently used method to protect against the harmful effects of surgical smoke. Such masks can have a 95-99\% bacterial filtration efficiency (BFE) and $91-95 \%$ particulate filtration efficiency (PFE). ${ }^{26}$ Sawchuke et al strongly suggested that the potential risk from surgical smoke inhalation may be markedly reduced by wearing a surgical mask. ${ }^{27}$ However, 
Oberg et al reported that no surgical mask exhibited adequate filtering performance and could eliminate smoke contaminants of $5 \mu \mathrm{m}$ in size. ${ }^{28}$ The remaining smoke diffused in the air and was then deposited on the walls of the surgeons' nose through masks, eventually causing HPV-related diseases in the surgeons. In the present study, we discovered that the presence of HPV DNA in surgical smoke was correlated with HPV infection in cervical cells. The genotypes detected in cervical cells and surgical smoke were identical. In addition, the distribution of HPV subtypes in the two doctors' nasal swabs was consistent with the genotypes detected in the corresponding cervical cell and surgical smoke samples. Furthermore, the LEEP operators in whom HR-HPV was detected in the nasal swab wore an ordinary mask, which may be less effective than an N95 mask in preventing virus infections.

Hospital operating room staff members are potentially exposed to hazardous chemicals, viable cells, bacteria and viruses in surgical smoke. Smoke evacuation devices have been shown to be effective in limiting exposure to the noxious odors and potential health hazards of smoke and plume, but they have not been used routinely and consistently in many operating rooms. ${ }^{29,30}$ Electrosurgical procedures open to the operating room environment may be more harmful than robotic or laparoscopic procedures with regard to uncontrolled surgical smoke emission. Therefore, it is important to ensure the use of smoke evacuation systems in the operating room.

In conclusion, our data proved the presence of HPV DNA in surgical smoke produced by LEEP. Additionally, our results suggested that the HPV DNA in the surgical plume is infectious and thus potentially harmful to healthcare professionals. Future studies should focus on longterm follow-up of gynecologic surgeons involved in LEEP. We also recommend the diligent use of high-filtration masks, in addition to smoke evacuation systems, by surgeons performing LEEP.

\section{Acknowledgments}

This work was supported by a grant from the Science and Technology Project of Zhejiang Province (grant number: 2014C33165). The study sponsors were not involved in the collection, analysis and interpretation of the data or in the writing of the manuscript.

\section{Author contributions}

All authors contributed to data analysis, drafting or revising the article, gave final approval of the version to be published, and agree to be accountable for all aspects of the work.

\section{Disclosure}

The authors have no conflicts of interest to declare in this work.

\section{References}

1. Siegel RL, Miller KD, Jemal A. Cancer statistics, 2019. CA Cancer J Clin. 2019;69:7-34.

2. Vink MA, Bogaards JA, van Kemenade FJ, et al. Clinical progression of high-grade cervical intraepithelial neoplasia: estimating the time to preclinical cervical cancer from doubly censored national registry data. Am J Epidemiol. 2013;178:1161-1169.

3. McCredie MR, Sharples KJ, Paul C, et al. Natural history of cervical neoplasia and risk of invasive cancer in women with cervical intraepithelial neoplasia 3: a retrospective cohort study. Lancet Oncol. 2008;9:425-434.

4. Gu Y, Ma C, Zou J, et al. Prevalence characteristics of high-risk human papillomaviruses in women living in Shanghai with cervical precancerous lesions and cancer. Oncotarget. 2016;7:24656-24663.

5. Duesing N, Schwarz J, Choschzick M, et al. Assessment of cervical intraepithelial neoplasia (CIN) with colposcopic biopsy and efficacy of loop electrosurgical excision procedure (LEEP). Arch Gynecol Obstet. 2012;286:549-554.

6. In SM, Park DY, Sohn IK, et al. Experimental study of the potential hazards of surgical smoke from powered instruments. Br J Surg. 2015;102:1581-1586.

7. Barrett WL, Garber SM. Surgical smoke: a review of the literature. Is this just a lot of hot air? Surg Endosc. 2003;17:979-987.

8. Kwak HD, Kim SH, Seo YS, et al. Detecting hepatitis B virus in surgical smoke emitted during laparoscopic surgery. Occup Environ Med. 2016;73:857-863.

9. Sagar PM, Meagher A, Sobczak S, et al. Chemical composition and potential hazards of electrocautery smoke. Br J Surg. 1996;83:1792.

10. Abramson AL, DiLorenzo TP, Steinberg BM. Is papillomavirus detectable in the plume of laser-treated laryngeal papilloma? Arch Otolaryngol Head Neck Surg. 1990;116:604-607.

11. Garden JM, O‘Banion MK, Shelnitz LS, et al. Papillomavirus in the vapor of carbon dioxide laser-treated verrucae. JAMA. 1988;259:1199-1202.

12. Sood AK, Bahrani-Mostafavi Z, Stoerker J, et al. Human papillomavirus DNA in LEEP plume. Infect Dis Obstet Gynecol. 1994;2:167170.

13. Hallmo P, Naess O. Laryngeal papillomatosis with human papillomavirus DNA contracted by a laser surgeon. Eur Arch Otorhinolaryngol. 1991;248:425-427.

14. Rioux M, Garland A, Webster D, et al. HPV positive tonsillar cancer in two laser surgeons: case reports. J Otolaryngol Head Neck Surg. 2013;42:54.

15. Kucera E, Sliutz G, Czerwenka K, et al. Is high-risk human papillomavirus infection associated with cervical intraepithelial neoplasia eliminated after conization by large-loop excision of the transformation zone? Eur J Obstet Gynecol Reprod Biol. 2001;100:72-76.

16. Resnick RM, Cornelissen MT, Wright DK, et al. Detection and typing of human papillomavirus in archival cervical cancer specimens by DNA amplification with consensus primers. J Natl Cancer Inst. 1990;82:1477-1484.

17. Sarma U, Mahanta J, Borkakoty B, et al. Distribution of human papilloma virus infections of uterine cervix among women of reproductive age-a cross sectional hospital-based study from North East India. Asian Pac J Cancer Prev. 2015;16:1519-1523. 
18. Calleja-Macias IE, Villa LL, Prado JC, et al. Worldwide genomic diversity of the high-risk human papillomavirus types $31,35,52$, and 58 , four close relatives of human papillomavirus type 16. $J$ Virol. 2005;79:13630-13640.

19. van Den Brule AJ, Meijer CJ, Bakels V, et al. Rapid detection of human papillomavirus in cervical scrapes by combined general primer-mediated and type-specific polymerase chain reaction. $J$ Clin Microbiol. 1990;28:2739-2743.

20. Garg R, Patil PK, Singh SV, et al. Comparative evaluation of different test combinations for diagnosis of mycobacterium avium subspecies paratuberculosis infecting dairy herds in India. Biomed Res Int. 2015;2015:983978

21. Walboomers JM, Jacobs MV, Manos MM, et al. Human papillomavirus is a necessary cause of invasive cervical cancer worldwide. J Pathol. 1999;189:12-19.

22. Wang R, Guo XL, Wisman GB, et al. Nationwide prevalence of human papillomavirus infection and viral genotype distribution in 37 cities in China. BMC Infect Dis. 2015;15:257.

23. Ferenczy A, Bergeron C, Richart RM. Human papillomavirus DNA in $\mathrm{CO}_{2}$ laser-generated plume of smoke and its consequences to the surgeon. Obstet Gynecol. 1990;75:114-118.
24. Kashima HK, Kessis T, Mounts P, et al. Polymerase chain reaction identification of human papillomavirus DNA in $\mathrm{CO}_{2}$ laser plume from recurrent respiratory papillomatosis. Otolaryngol Head Neck Surg. 1991;104:191-195.

25. Weyandt GH, Tollmann F, Kristen P, et al. Low risk of contamination with human papilloma virus during treatment of condylomata acuminata with multilayer argon plasma coagulation and $\mathrm{CO}_{2}$ laser ablation. Arch Dermatol Res. 2011;303:141-144.

26. Fan JK, Chan FS, Chu KM. Surgical smoke. Asian J Surg. 2009;32:253-257.

27. Sawchuk WS, Weber PJ, Lowy DR, et al. Infectious papillomavirus in the vapor of warts treated with carbon dioxide laser or electrocoagulation: detection and protection. $J$ Am Acad Dermatol. 1989;21:41-49.

28. Oberg T, Brosseau LM. Surgical mask filter and fit performance. Am J Infect Control. 2008;36:276-282.

29. Hoglan M. Potential hazards from electrosurgery plume-recommendations for surgical smoke evacuation. Can Oper Room Nurs J. 1995;13:10-16.

30. Springer R. Surgical smoke. Plast Surg Nurs. 2007;27:221-222. 


\section{Supplementary materials}

Table SI The association between HPV DNA in exfoliated cervical cells and surgical smoke

\begin{tabular}{|l|l|l|l|l|}
\hline & \multicolumn{2}{|l|}{ Surgical smoke } & $\chi 2$ value & P-value \\
\hline & Positive & Negative & & \\
\hline $\begin{array}{l}\text { Exfoliated cervical cells } \\
\text { Positive }\end{array}$ & 40 & & 9.06 & 0.002 \\
Negative & 0 & 87 & & \\
\hline
\end{tabular}

Table S2 Multivariate analysis of the correlation of HPV infection in surgical smoke with the location of the surgical smoke collection from the top of suction device

\begin{tabular}{|c|c|c|c|}
\hline Factor & Regression coefficient & OR & $95 \% \mathrm{Cls}$ \\
\hline Location of the surgical smoke collection from the top of suction device & 1.604 & 5.0 & $1.4-17.6$ \\
\hline
\end{tabular}

Abbreviations: OR, the odds ratio; $\mathrm{Cls}, 95 \%$ confidence intervals.

\section{Publish your work in this journal}

Cancer Management and Research is an international, peer-reviewed open access journal focusing on cancer research and the optimal use of preventative and integrated treatment interventions to achieve improved outcomes, enhanced survival and quality of life for the cancer patient.
The manuscript management system is completely online and includes a very quick and fair peer-review system, which is all easy to use. Visit http://www.dovepress.com/testimonials.php to read real quotes from published authors 